\title{
INFLUENCE OF PUMP PRESSURE AND ENGINE SPEED ON ERGONOMIC PARAMETERS OF FORWARDER OPERATORS
}

\author{
Diego Weslly Ferreira do Nascimento Santos $2^{*}\left(\mathcal{C}\right.$, Domingos Sárvio Magalhães Valente ${ }^{3}$,Haroldo Carlos
}

Fernandes $^{3} \odot$, Amaury Paulo de Souza ${ }^{4} \odot$ and Luciano José Minette ${ }^{4} \odot$

\footnotetext{
${ }^{1}$ Received on 06.09.2019 accepted for publication on 01.04.2020.

${ }^{2}$ Universidade Federal de Lavras, Departamento de Engenharia, Lavras, MG - Brasil. E-mail: < diegoweslley89@hotmail.com>.

${ }^{3}$ Universidade Federal de Viçosa, Departamento de Engenharia Agrícola, Viçosa, MG - Brasil. E-mail: < valente@ufv.br>and <haroldoufv@ gmail.com>.

${ }^{4}$ Universidade Federal de Viçosa, Departamento de Engenharia Florestal, Viçosa, MG - Brasil. E-mail: <amaury@ufv.br> and <minette@ ufv.br>.

*Corresponding author.
}

\begin{abstract}
Reducing engine speed and pressure of forest machine hydraulic pumps may be a strategy to achieve a reduction in fuel costs. However, this approach can positively or negatively affect the ergonomic parameters of the operators, in particular, the whole-body vibration and repetitive movements of the operators. The objective of this research was to evaluate the acceleration force resulting from normalized exposure (Aren) and the Real Occupancy Rate and Maximum Occupancy Rate considering Repetitive Activities (RORMORCRA) of forwarder operating at different pump pressures, engine speed, and volume of trees. The research was carried out in forest stands with an individual average volume of $0.10,0.14$, and $0.29 \mathrm{~m}^{3}$ tree $^{-1}$. For each volume, the machine was configured to operate at hydraulic pump pressures of 240, 235, and 230 bar and engine speed of 1550,1475, and $1400 \mathrm{rpm}$, totaling 9 combinations. The values were measured in the 9 combinations and also in each phase of the machine operational cycle, using a triaxial accelerometer of the $01 \mathrm{~dB}$ brand, model Vib 008. To determine ROR, percentage of rest due to regular breaks, percentage of time with low demand activities, percentage of usual irregular breaks, and percentage of very short breaks were calculated. To estimate MORCRA, the repetition, strength, and static effort factors were calculated. In volumes of $0.10,0.14$, and $0.29 \mathrm{~m}^{3}$ tree $^{-1}$, the highest Aren values were $0.82,0.88$, and $0.99 \mathrm{~m} \mathrm{~s}^{-2}$, respectively, being obtained at the $1550 \mathrm{rpm}$ engine speed. The forwarder logging operation is characterized as an ergonomic risk, which can cause discomfort, fatigue, and injuries to operators.
\end{abstract}

Keywords: Wood extraction; Occupational diseases; Forest harvest.

\section{INFLUÊNCIA DA PRESSÃO DA BOMBA E ROTAÇÃO DO MOTOR SOBRE PARAMMTROS ERGONÔMICOS DE OPERADORES DE FORWARDER}

RESUMO - A redução do regime de rotação do motor e pressão da bomba hidráulica de máquinas florestais poderá ser uma alternativa para proporcionar a redução do custo com combustível, contudo podendo afetar de forma positiva ou negativa parâmetros ergonômicos dos operadores, em especial a vibração de corpo inteiro e movimento repetitivos de operadores. Objetivou-se com a presente pesquisa avaliar os valores de Aceleração resultante de exposição normalizada (Aren) e o índice de Taxa de Ocupação Real e Taxa de Ocupação Máxima Considerando Atividades Repetitivas (TOR-TOMCAR) de forwarder operando em diferentes pressões da bomba, rotação do motor e volume das árvores. A pesquisa foi executada em povoamentos florestais com volume médio individual de 0,10; 0,14; e 0,29 $\mathrm{m}^{3}$ árvore $e^{-1}$. Em cada volume, a máquina foi configurada para operar nas pressões da bomba hidráulica de 240; 235; e 230 bar e rotações do motor de 1.550; 1.475; e $1.400 \mathrm{rpm}$, totalizando 9 combinações. Os valores de Aren foram mensurados nas 9 combinações e também em cada fase do ciclo operacional da máquina, sendo utilizado um acelerômetro do tipo triaxial, da marca 01dB, modelo Vib 008. Para determinar a TOR, foram calculadas a Porcentagem de repouso por pausas regulares, porcentagem de tempo com atividades de baixa exigência, porcentagem de pausas irregulares habituais $e$ porcentagem de pausas curtíssimas. Para estimar a TOMCAR foram calculados o Fator Repetitividade, Força e Esforço Estático. Nos volumes de 0,10; 0,14; e 0,29 $\mathrm{m}^{3}$ arv $v^{-1}$ os maiores valores de Aren foram de 0,82; 0,88;

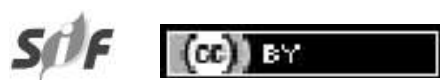

Revista Árvore 2020;44:e4425 http://dx.doi.org/10.1590/1806-908820200000025 


\begin{abstract}
e $0,99 \mathrm{~m} \mathrm{~s}^{-2}$, respectivamente, sendo obtidos na rotação do motor de $1.550 \mathrm{rpm}$. A operação de extração de madeira com forwarder se caracteriza como de risco ergonômico, podendo causar desconforto, fadiga e lesões aos operadores.
\end{abstract}

Palavras-Chave: Extração de madeira; Doenças ocupacionais; Colheita florestal.

\section{INTRODUCTION}

The forwarder is a self-loading forestry tractor used in the extraction of wood from the felling site to the roadsides or intermediate yard. Among the wood extraction machines, the forwarder provides the best ergonomic conditions for operators (Gerasimov and Sokolov, 2014). Despite the advantages of the forwarder operation, it has a high operating cost, and fuel is the fourth greatest expense, representing about 14\% of the total cost (Santos et al., 2016; Robert et al., 2018). Reducing engine speed and hydraulic pump pressure is an alternative that has been used to reduce the hourly fuel consumption of machines and consequently the overall cost (Prinz et al., 2018; Santos et al., 2018).

All functions of the forwarder, such as the driving the hydraulic crane, crane claw, and movement of the machine, are operated with electronic handles that require different competencies and skills from the operators. Thus, changes in engine and hydraulic pump settings can affect operator ergonomic factors, as they already suffer from occupational diseases. The forwarder operation is known to cause Repetitive Strain Injury and can also cause nervousness and irritation (Silva et al., 2013). Also, forwarder operators are exposed to wholebody vibration values of $1.69 \mathrm{~m} \mathrm{~s}^{-2}$, and preventive measures are required to reduce the vibration values (Rehn at al., 2005).

Occupational diseases in forest machine operators occur because, during operation, workers sit for long periods in ergonomically inadequate positions, are exposed to full-body vibration, and perform repetitive short cycle movements (Gerasimov and Sokolov, 2014). Exposure to whole-body vibration has been identified as a cause of musculoskeletal disorders, such as low back pain and herniated discs (Osborne et al., 2012). Despite all the technology used in forest harvesting machines, the levels of exposure to vibrations are over the limits recommended by the relevant standards (Almeida et al., 2015).

Based on the above, the objective of this research was to evaluate the acceleration force value resulting from normalized exposure and the Index of Real
Occupancy Rate and Maximum Occupancy Rate Considering Repetitive Activities of the forwarder operating at different engine speeds, hydraulic pump pressure, and volume of trees.

\section{MATERIAL AND METHODS}

\subsection{Study area}

The research was carried out in Brazil in the municipality of Nova Viçosa - BA. The region has an average annual temperature of $24.4^{\circ} \mathrm{C}$ and an average annual rainfall of $1350 \mathrm{~mm}$. The area had a flat relief, populated with hybrid clones of Eucalyptus grandis $\mathrm{x}$ Eucalyptus urophylla, planted at a distance of 4 meters between rows and 2.5 meters between plants. The evaluations were conducted during the day, starting at $06 \mathrm{~h} 00$ and ending at $15 \mathrm{~h} 00$.

\subsection{Harvesting system}

The research was carried out in a cut-to-length forest harvesting system composed of harvester and forwarder machines. The harvester carried out the cutting and processing trees, leaving $6.20 \mathrm{~m}$ long logs on the soil surface. The machine simultaneously felled four tree lines. The forwarder carried out the extraction of wood starting from the interior of the fields and worked towards to the roadsides.

\subsection{Experimental units}

The research was carried out at volumes of 0.10 , 0.14 , and $0.29 \mathrm{~m}^{3}$ tree $^{-1}$. In each volume, the forwarder was configured to operate with a hydraulic pump pressure of 240, 235, and 230 bar and at engine speeds of 1550 , 1475 , and $1400 \mathrm{rpm}$, totaling 9 treatments and with 4 repetitions each. One repetition was equivalent to a work shift, that is, 7.4 hours of effective work. The company where the research was carried out used the machine with a pump pressure of 240 bar and engine speed of $1400 \mathrm{rpm}$, which was the standard configuration.

\subsection{Machine used}

The Komatsu model 895 forwarder was used. The machine was equipped with the 6-cylinder AGCO power

Revista Árvore 2020;44:e4425 
74CW3 engine with $193 \mathrm{~kW}$ of power at $1950 \mathrm{rpm}$. The hydraulic system consisted of a hydraulic piston pump with a maximum flow of 360 liters per minute at 2000 $\mathrm{rpm}$ and a maximum working pressure of $24.5 \mathrm{MPa}$.

\subsection{Determination of individual tree volume}

The individual average volume (IAV) was determined using the diameter and length sensors on the harvester head. Subsequently, the VMI was calculated by the MaxiXplorer machine operating system. The length sensor was positioned on the head feed rollers, and the diameter sensor was positioned on the delimbing knives of the head. The sensors were calibrated before the research was carried out.

\subsection{Hydraulic pump pressure selection}

The forwarder hydraulic pump was configured to pressures of 240, 235, and 230 bar. Values were obtained by manually adjusting the hydraulic pump. Hydraulic circuit pressure values were instantly displayed on the machine monitor through the MaxiXplorer operating system.

\subsection{Engine speed selection}

The forwarder was programmed to work at engine speeds of 1550,1475 , and $1400 \mathrm{rpm}$. The values were selected by the operator and controlled by the MaxiXplorer Control and Information System.

\subsection{Assessment whole-body vibration}

The whole-body vibration values were measured according to the technical recommendations established by the Occupational Hygiene Standard 09 (FUNDACENTRO, 2013). The measurements were taken with a triaxial accelerometer from the manufacturer $01 \mathrm{~dB}$, model Vib 008. The device was fixed to the operator seat and positioned according to the three directions of the orthogonal coordinate system $(\mathrm{x}, \mathrm{y}$, and $\mathrm{z}$ ). The acceleration force values resulting from normalized exposure (Aren) were measured for all the three volumes surveyed and in all combinations of pump pressure and engine speed. The Aren values were also measured at each stage that make up the forwarder operating cycle.

To account for the Aren values per operation, a video system was installed in the operator cabin. The timing of the video system was adjusted in relation to the time of the accelerometer. The forwarder operational cycle was divided into the following steps: empty travel, loading, loaded travel, and unloading. The data were processed using the dBMaestro 5.5 software.

\subsection{Real Occupancy Rate (ROR) - Maximum Occupancy Rate Considering Repetitive Activities (MORCRA)}

The potential of the forwarder operation to cause disorders such as fatigue, discomfort, difficulties, and injuries was quantified through the ROR (Real Occupancy Rate) - MORCRA (Maximum Occupancy Rate Considering Repetitive Activities) index (Couto, 2012). ROR was calculated using Equation 1.

$$
R O R=100 \%-P B R-P T D A-P U I B-P V S B \text { (Eq.1) }
$$

Where: $\mathrm{ROR}=$ real occupancy rate $(\%)$; $\mathrm{PRB}=$ Percentage of rest due to regular breaks (\%); PTDA $=$ Percentage of time with low demand activities (\%); PUIB $=$ Percentage of usual irregular breaks (\%); and PVSB $=$ Percentage of very short breaks $(\%)$.

To determine the PRB, all short breaks times were quantified (ret, bathroom breaks, smoking, stretching). Regarding the PTDA, the time spent on inspection of the machine at the beginning of the workday and cleaning and organization of the machine at the end of the workday was measured. To account for the time spent with very short breaks during the work, a video system was installed in the operator cabin. The video system consisted of four video cameras, a seven-inch monitor, and a Mobile Digital Video Recorder (MVDR). The first camera was aimed at the left and right joystick, the second at the operator head, the third at the cargo box, and the fourth at the right side of the forwarder. Videos of 13 forwarder operating cycles were recorded in each combination with pump pressure and engine speed. Subsequently, the recorded content was analyzed to determine if there were very short pauses between cycles or within the cycle. Only short breaks with intervals of at least three seconds were considered.

The Maximum Occupancy Rate Considering Repetitive Activities was calculated according to Equation 2.

$$
M O R C R A=95 \%-R F-F F-S E F
$$

Where: MORCRA = Maximum Occupancy Rate Considering Repetitive Activities (\%); RF = Repeatability Factor (\%); FF = Force Factor (\%); and $\mathrm{SEF}=$ Static Effort Factor (\%).

\section{Revista Árvore 2020;44:e4425}


The repeatability, strength, and static effort factors were determined according to flowcharts and tables (Couto, 2012). To facilitate the study of repetitiveness, the components and the respective functions, triggered by the forwarder operators (Table 1), were identified.

At the beginning, middle, and end of the workday, operators answered a questionnaire in order to identify the occurrence or absence of fatigue caused by the operation (Couto, 2012).

\subsection{Data analysis}

The acceleration force value data resulting from normalized exposure with respect to combinations of pump pressure and engine speed within each volume were analyzed using a response surface methodology. The models were selected based on the determination coefficient, behavior of the phenomenon under study, and the significance of the regression coefficients, using the Student's t-test and adopting the 5\% probability level.

The acceleration force values resulting from normalized exposure per operation performed on the three volumes studied were analyzed using Analysis of Variance and compared by the Tukey test when significant at the level of 5\% probability. A completely randomized design (CRD) was adopted in a $3 \times 4$ factorial scheme, with three volumes of wood, and four phases of the machine's operational cycle, totaling 12 treatments with 4 repetitions each.

\section{RESULTS}

\subsection{Full-body vibration}

There was no significant effect of the pump pressure on the Aren values in any of the studied wood volumes. The engine speed had a significant, linear, and positive influence on the Aren values in all studied volumes (Figure 1). In volumes of $0.10,0.14$, and $0.29 \mathrm{~m}^{3}$ tree $^{-1}$, the highest Aren values were 0.82, 0.88, and 0.99 $\mathrm{m} \mathrm{s}^{-2}$, respectively, and there were obtained at the engine speed of $1550 \mathrm{rpm}$. At volumes of $0.10,0.14$, and 0.29 $\mathrm{m}^{3}$ tree ${ }^{-1}$, the $10 \mathrm{rpm}$ increase in engine speed caused an increase of $0.021,0.008$, and $0.008 \mathrm{~m} \mathrm{~s}^{-2}$ in the Aren values, respectively.

The acceleration force values resulting from the normalized exposure of the loading and loaded travel operations suffered a significant effect from the volume of trees, and in the other operations, there was no significant effect (Table 2). The Aren values also suffered a significant effect on the type of operation performed by the machine, observing the highest values for empty travel operation.

\subsection{ROR-MORCRA index}

There were no significant differences between the values of the Real Occupancy Rate (ROR) and the Maximum Occupancy Rate considering repetitive activities (MORCRA) in the three volumes studied (Table 3). The ROR-MORCRA values were the same in the 9 combinations of pump pressure and engine speed. During the execution of the research, there were no habitual irregular breaks, very short breaks, and force factors observed. MORCRA was 12.58, 10.96, 10.75\% lower than ROR at volumes of $0.10,0.14$, and $0.29 \mathrm{~m}^{3}$ tree $^{-1}$, respectively. Thus, the forwarder wood extraction operation is characterized as an ergonomic risk, which can cause discomfort, fatigue, and injuries to operators. The reduction in pump pressure and engine speed did not intensify the occurrence of occupational diseases in operators.

Table 4 presents the movements performed by the operator during the working day in the three volumes studied, as well as in the various combinations of pump pressure and engine speed. The forwarder operation is characterized as repetitive with simultaneous movements of the hands, wrists, and fingers; however, these are minmal.

Table $1-895$ forwarder commands and respective functions.

Tabela 1 - Comandos do forwarder 895 e as respectivas funções.

\begin{tabular}{lc}
\hline Components & Functions \\
\hline Right dome - Joystick & $\begin{array}{c}\text { Vertical movement of the hydraulic crane and turning } \\
\text { rotator }\end{array}$ \\
\hline Right dome - Joystick button & Opening and closing the hydraulic grapple \\
\hline Right dome - button 1 & Angled left or right movement of the machine \\
\hline Left dome - Joystick & Hydraulic crane extension, contraction, and rotation \\
\hline Left dome - button 5 and 8 & Vertical movement of the front grille of the cargo box \\
\hline Gas pedal & Machine travel \\
\hline
\end{tabular}

Revista Árvore 2020;44:e4425 
A

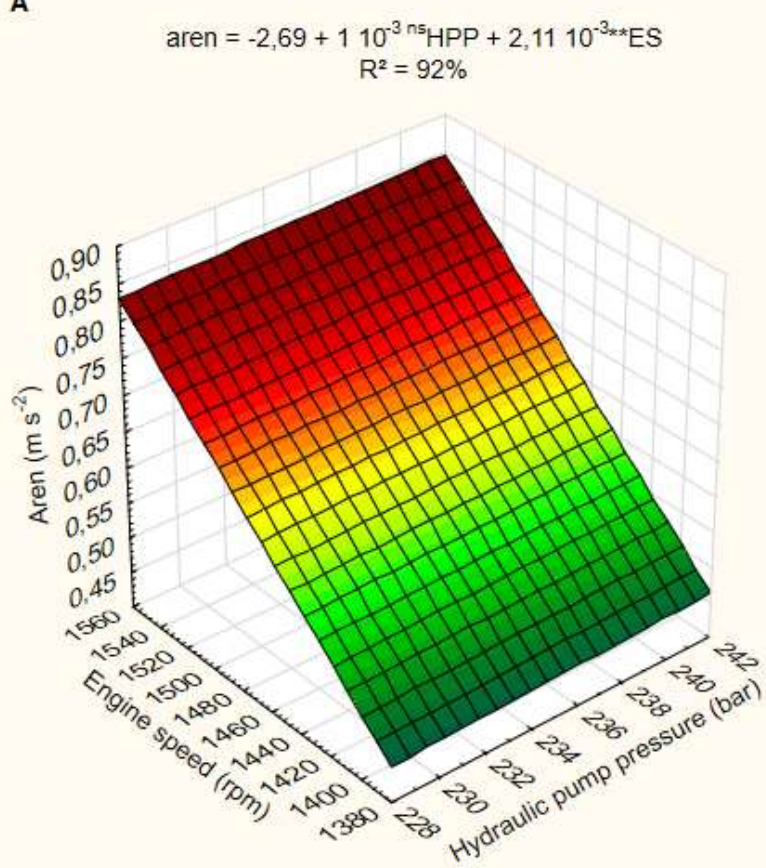

B

$$
\begin{gathered}
\text { aren }=-4,27410^{-1}+410^{-4}{ }^{n s} \mathrm{HPP}+7,8310^{-4 \times \star} \mathrm{ES} \\
\mathrm{R}^{2}=97 \%
\end{gathered}
$$

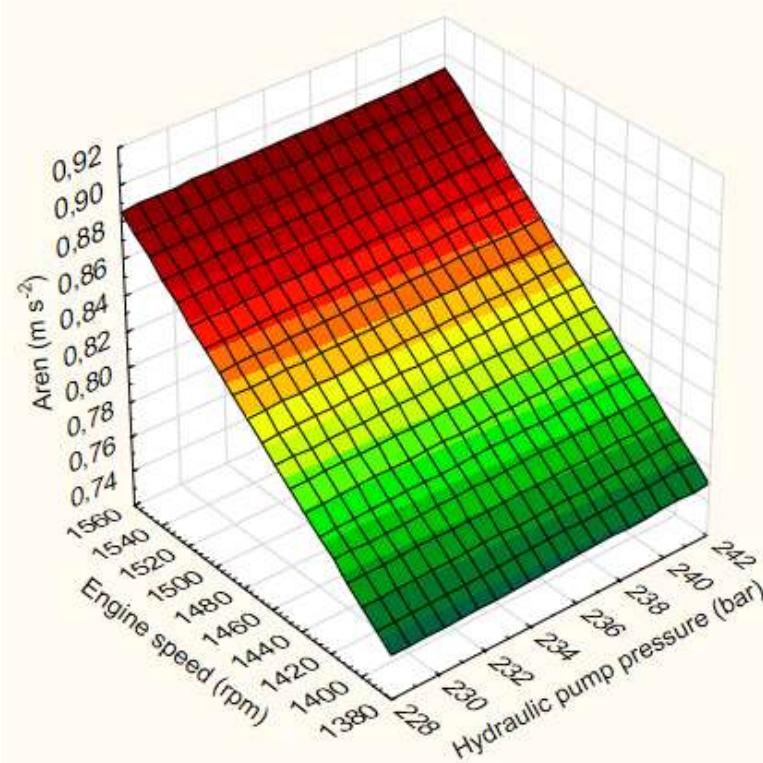

C

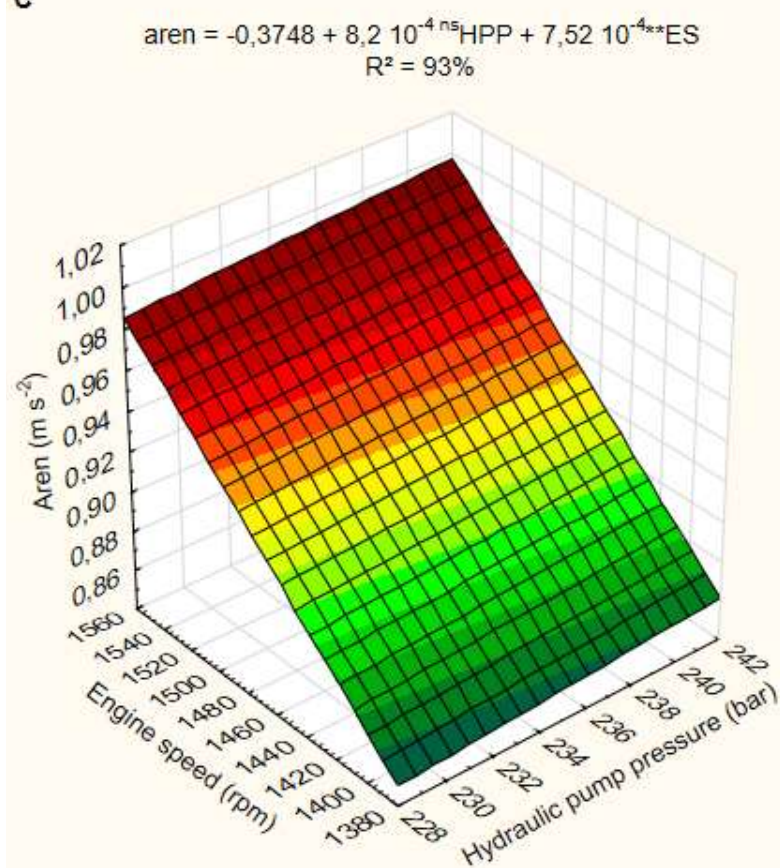

Figure 1 - Response surface and adjusted equation of the acceleration force value resulting from normalized exposure (Aren) as a function of hydraulic pump pressure (HPP) and engine speed (ES). Where: $\mathrm{A}=$ volume of $0.10 \mathrm{~m}^{3}$ tree $^{-1} ; \mathrm{B}=$ volume of $0.14 \mathrm{~m}^{3}$ tree ${ }^{-1} ; \mathrm{C}$ $=$ volume of $0.29 \mathrm{~m}^{3}$ tree ${ }^{-1} ; * *=$ significant at the $1 \%$ probability level; $\mathrm{ns}=$ not significant; and $\mathrm{R}^{2}=$ coefficient of determination

Figura 1 - Superfície de resposta e Equação ajustada da Aceleração resultante de exposição normalizada (Aren) em função da pressão da bomba $(P B)$ e rotação do motor (RM). Onde: $A=$ volume de $0,10 \mathrm{~m}^{3}$ árvore-1: $B=$ volume de $0,14 \mathrm{~m}^{3}$ árvore- ${ }^{1} \mathrm{C}=$ volume de $0,29 \mathrm{~m}^{3}$ árvore $^{-1} ; * *=$ significativo ao nível de $1 \%$ de probabilidade; $n s=$ não significativo; e $R^{2}=$ coeficiente de determinação. 


\section{DISCUSSION}

\subsection{Full-body vibration}

The acceleration force values resulting from normalized exposure did not exceed the limit value for the 8-hour working day in all scenarios studied (FUNDACENTRO, 2013; ISO 2631-1, 1997). However, at the low and medium tree volumes, the values are above the threshold, requiring the adoption of preventive measures. At the greatest volume studied, the Aren values are in a range of uncertainty, requiring the adoption of both preventive and corrective measures. Preventive measures that can be adopted include: reduction of engine speed, an increase of regular breaks during the working day, and change of the machine suspension from the bogie type to the pendulum type system. Bogie suspension systems are the most efficient for forestry machines and can reduce vibration levels by up to $50 \%$ (Ismoilov et al., 2015).

In research carried out with different types forwarders, an average Aren value of $0.70 \mathrm{~m} \mathrm{~s}^{-2}$ was observed. These values were lower than that observed in the current research, whtich resuled from differences in operating conditions and machines used in the research (Marzano et al., 2017). The forwarder vibration values are influenced by the different models of the machines and operators (Rehn et al., 2005).

At the volume of $0.29 \mathrm{~m}^{3}$ tree-1, the Aren value of the loading operation was statistically higher than the values of the other operations at the same volume. The result is justified because during loading, some logs were released at a certain distance from the surface of the cargo box, causing a larger impact. Larger volume logs are heavier, and therefore, they caused greater impacts on the cargo box and, consequently, higher Aren values

Table 2 - Acceleration force values per operation resulting from normalized exposure (Aren) of the forwarder in the surveyed volumes.

Tabela 2 - Valores, por operação, de aceleração resultante de exposição normalizada (Aren) do forwader nos volumes pesquisados.

\begin{tabular}{llccr}
\hline Volume & \multicolumn{4}{c}{ Operation } \\
\cline { 2 - 5 }$\left(\mathrm{m}^{3}\right.$ tree $\left.^{-1}\right)$ & Empty travel & Loading & Loaded travel & Unloading \\
\hline 0.10 & $0.45 \mathrm{Aa}$ & $0.34 \mathrm{Cb}$ & $0.39 \mathrm{Aab}$ & $0.26 \mathrm{Ac}$ \\
0.14 & $0.51 \mathrm{Aa}$ & $0.45 \mathrm{Bab}$ & $0.40 \mathrm{Abc}$ & $0.33 \mathrm{Ac}$ \\
0.29 & $0.50 \mathrm{Aa}$ & $0.55 \mathrm{Aa}$ & $0.35 \mathrm{Bb}$ & $0.35 \mathrm{Ab}$ \\
\hline
\end{tabular}

Means followed by the same letter, uppercase in the columns and lowercase in the rows, do not differ between each other by the Tukey test at the $99 \%$ probability level.

Médias seguidas pela mesma letra, maiúsculas nas colunas e minúsculas nas linhas, não diferem entre se pelo teste de Tukey ao nivel de $99 \%$ de probabilidade. were transmitted to operators. At the volume of $0.29 \mathrm{~m}^{3}$ tree $^{-1}$, the Aren value of the loaded travel operation was statically lower than the others of the same volume. It is possible that the heavier wood acted as a ballast, thus providing more stability to the machine and reduced the Aren values.

The higher values for full-body vibration during empty travel operation are due to the machine travel speed, which was $1.59 \mathrm{~m} \mathrm{~s}^{-1}$. Additionally, the machine carried out the displacement on uneven soil surface, given the presence of stumps and stones. The statistically lower aren values for the unloading operation, on the other hand, are attributed to performing the operation while the machine is parked and without sudden movements. In another research, the highest Aren values, in decreasing order, were obtained for operations, such as empty travel, loaded travel, loading, and unloading (Rehn et al., 2005). Similar results to the current research have been previously reported, despite the differences in the type and characteristics of the soil, machine, operator, travel speed, extraction distance, and tree volume.

\subsection{ROR-MORCRA INDEX}

From these results, it became evident that it is necessary to increase breaks during the work day in order to provide a reduction in ROR and an increase in

Table 3 - Real Occupancy Rate (ROR) and Maximum Occupancy Rate Considering Repetitive Activities (MORCRA) in all volumes surveyed.

Tabela 3 - Taxa de Ocupação Real (TOR) e Taxa de Ocupação Máxima Considerando Atividades Repetitivas (TOMCAR) em todos os volumes pesquisados.

\begin{tabular}{|c|c|c|c|}
\hline \multirow[t]{2}{*}{ Pause type } & \multicolumn{3}{|c|}{ Volume $\left(\mathrm{m}^{3}\right.$ tree $\left.^{-1}\right)$} \\
\hline & 0.10 & 0.14 & 0.29 \\
\hline PRB (\%) & 7.29 & 7.50 & 8.13 \\
\hline PTDA (\%) & 3.13 & 3.54 & 3.13 \\
\hline PUIB (\%) & 0.00 & 0.00 & 0.00 \\
\hline PVSB $(\%)$ & 0.00 & 0.00 & 0.00 \\
\hline Regulation mechanism (\%) & 5.00 & 5.00 & 5.00 \\
\hline ROR (\%) & 84.58 & 83.96 & 83.75 \\
\hline RF (\%) & 2.00 & 2.00 & 2.00 \\
\hline $\mathrm{FF}(\%)$ & 0.00 & 0.00 & 0.00 \\
\hline $\mathrm{SEF}(\%)$ & 21.00 & 20.00 & 20.00 \\
\hline MORCRA $(\%)$ & 72.00 & 73.00 & 73.00 \\
\hline \multicolumn{4}{|c|}{$\begin{array}{l}\text { Where: } \mathrm{PRB}=\text { Percentage of rest due to regular breaks }(\%) ; \mathrm{PTDA}=\text { Percenta- } \\
\text { ge of time with low demand activities }(\%) ; \mathrm{PUIB}=\text { Percentage of usual irregu- } \\
\text { lar breaks }(\%) ; \mathrm{PVSB}=\text { Percentage of very short breaks }(\%) ; \mathrm{RF}=\text { repeatability } \\
\text { factor; } \mathrm{FF}=\text { force factor; and } \mathrm{SEF}=\text { static effort factor. } \\
\text { Em que: } P P R=\text { Porcentagem de repouso por pausas regulares }(\%) ; P A B E \\
=\text { Porcentagem de tempo com atividades de baixa exigência }(\%) ; P P I H= \\
\text { Porcentagem de pausas irregulares habituais }(\%) ; P P C=\text { Porcentagem de } \\
\text { pausas curtissimas }(\%) ; F R=\text { fator repetitividade; } F F=\text { fator força; } \text { e FEE }= \\
\text { fator esforço estático. }\end{array}$} \\
\hline
\end{tabular}

Revista Árvore 2020;44:e4425 
Table 4 - Number of times, per shift, that the operator activated the machine commands in all the scenarios surveyed.

Tabela 4 - Número de vezes, por turno, que o operador acionava os comandos da máquina em todos os cenários pesquisados.

\begin{tabular}{|c|c|c|c|c|c|c|c|c|}
\hline \multirow{2}{*}{$\begin{array}{l}\text { Volume } \\
\left(\mathrm{m}^{3} \text { tree }^{-1}\right)\end{array}$} & \multirow{2}{*}{$\begin{array}{l}\text { Hydraulic pump } \\
\text { pressure (bar) }\end{array}$} & \multirow{2}{*}{$\begin{array}{l}\text { Engine speed } \\
\text { (rpm) }\end{array}$} & \multicolumn{6}{|c|}{ Command } \\
\hline & & & A & B & C & D & E & $\mathrm{F}$ \\
\hline \multirow{9}{*}{0.10} & 240 & 1550 & 858 & 1291 & 4660 & 4854 & 47 & 2492 \\
\hline & 240 & 1475 & 856 & 1288 & 4649 & 4843 & 47 & 2486 \\
\hline & 240 & 1400 & 855 & 1287 & 4644 & 4838 & 47 & 2483 \\
\hline & 235 & 1550 & 848 & 1276 & 4606 & 4798 & 46 & 2463 \\
\hline & 235 & 1475 & 844 & 1270 & 4584 & 4775 & 46 & 2451 \\
\hline & 235 & 1400 & 851 & 1281 & 4623 & 4816 & 47 & 2472 \\
\hline & 230 & 1550 & 857 & 1289 & 4651 & 4845 & 47 & 2487 \\
\hline & 230 & 1475 & 852 & 1282 & 4626 & 4819 & 47 & 2473 \\
\hline & 230 & 1400 & 852 & 1282 & 4627 & 4819 & 47 & 2474 \\
\hline \multirow{9}{*}{0.14} & 240 & 1550 & 825 & 1309 & 4145 & 4325 & 50 & 2222 \\
\hline & 240 & 1475 & 823 & 1306 & 4135 & 4314 & 50 & 2217 \\
\hline & 240 & 1400 & 747 & 1185 & 3751 & 3913 & 46 & 2011 \\
\hline & 235 & 1550 & 824 & 1307 & 4139 & 4319 & 50 & 2219 \\
\hline & 235 & 1475 & 823 & 1306 & 4135 & 4315 & 50 & 2217 \\
\hline & 235 & 1400 & 744 & 1180 & 3737 & 3899 & 45 & 2004 \\
\hline & 230 & 1550 & 826 & 1310 & 4149 & 4329 & 50 & 2224 \\
\hline & 230 & 1475 & 817 & 1296 & 4102 & 4280 & 50 & 2199 \\
\hline & 230 & 1400 & 745 & 1183 & 3745 & 3907 & 45 & 2008 \\
\hline \multirow{9}{*}{0.29} & 240 & 1550 & 736 & 1252 & 3426 & 3577 & 51 & 1839 \\
\hline & 240 & 1475 & 710 & 1209 & 3306 & 3452 & 50 & 1775 \\
\hline & 240 & 1400 & 684 & 1164 & 3184 & 3325 & 48 & 1709 \\
\hline & 235 & 1550 & 739 & 1259 & 3443 & 3595 & 52 & 1848 \\
\hline & 235 & 1475 & 703 & 1197 & 3274 & 3419 & 49 & 1758 \\
\hline & 235 & 1400 & 683 & 1163 & 3180 & 3321 & 48 & 1707 \\
\hline & 230 & 1550 & 726 & 1237 & 3382 & 3532 & 51 & 1816 \\
\hline & 230 & 1475 & 691 & 1176 & 3217 & 3359 & 48 & 1727 \\
\hline & 230 & 1400 & 676 & 1151 & 3150 & 3289 & 47 & 1691 \\
\hline
\end{tabular}

MORCRA. Such measures can reduce the occurrence of occupational diseases in operators. Forest machine operators are susceptible to neck, arm, and cervical spine injuries, all caused by the excessive strain during work, staying in ergonomically incorrect fixed positions for a long time, and due to repetitive short cycle movements (Gerasimov and Sokolov, 2014). Also, the prevalence of discomfort and pain in forest machine operators may be related to organizational factors (Østensvik et al., 2008).

The reduction of pump pressure and engine speed did not intensify the occurrence of occupational diseases. However, the hydraulic crane and gripper movements became more difficult to controll when the machine was configured to operate at the engine speed of 1550 $\mathrm{rpm}$, regardless of the pump pressure, as it became more powerful and aggressive. During the execution of the research, it was evident that operators were not used to such rotation, and it can have either a negative or positive effect on the operator ergonomics and productivity in the long term.

At the smallest volume studied, these extraction processes were repeated more times to completely fill the machine cargo box, due to the greater number of wooden bundles necessary. The right joystick was the command most used by the operator in all scenarios studied. The result is justified because this component had the function of activating the hydraulic cylinder that made it possible to raise and lower (vertical movement) the hydraulic crane and also to activate the hydraulic rotator that controlled the rotational movement of the gripper. The second most used component was the left joystick, which was used to drive the hydraulic cylinder that corresponded to the extension and contraction of the hydraulic crane, in addition to the mechanism that promoted the rotational movement of the hydraulic crane. Both joysticks were hand controlled by the 
operators, requiring vertical and horizontal movements of the handles. From the results, it appears that the forwarder operation is characterized as repetitive, with simple simultaneous movements of hands, wrists, and fingers. These results corroborate those found in another study, in which $90 \%$ of workers considered the operation to be repetitive (Silva et al., 2013).

\section{CONCLUSIONS}

The Aren values of the forwarder operation do not exceed the limit for the eight-hour working day; however, it is necessary to adopt preventive measures. The increase in the volume of the wood and the engine speed causes a significant increase in the Aren values. The empty travel operation exposes operators to the highest magnitudes of full-body vibration.

The forwarder operation was characterized as repetitive, requiring simple, simultaneous movements of the hands, wrists, and fingers. Besides, it is an ergonomic risk operation, which can cause occupational diseases, such as fatigue, physical, and mental tiredness, compromising operator productivity and also resulting in pain in the arm, wrist, and hands on both left and right side. However, the reduction in pump pressure and engine speed did not intensify the occurrence of occupational diseases in forwarder operators.

\section{ACKNOWLEDGMENTS}

This study was financed in part by the Coordenação de Aperfeiçoamento de Pessoal de Nível Superior Brasil (CAPES) - Finance Code 001 and Conselho Nacional de Desenvolvimento Científico e Tecnológico (CNPq).

\section{REFERENCES}

Almeida SF, Abrahão RF, Tereso MJA. Avaliação da exposição ocupacional à vibração de corpo inteiro em máquinas de colheita florestal. Cerne. 2015;21(1):1-8. doi:10.1590/01047760201521011446

Couto HA. Índice TOR-TOM: 25 aplicações práticas na análise ergonômica, na avaliação de risco ergonômico, na prescrição de ações corretivas e no gerenciamento da produtividade segura. $2^{\mathrm{a}}$. ed. Belo horizonte: Ergo; 2012.

Fundação Jorge Duprat Figueiredo de Segurança e
Medicina do Trabalho - FUNDACENTRO. Norma de Higiene Ocupacional: NHO 09: Avaliação da exposição ocupacional a vibrações de corpo inteiro. São Paulo: Fundação Jorge Duprat Figueiredo de Segurança e Medicina do Trabalho; 2013.

Gerasimov Y, Sokolov A. Ergonomic evaluation and comparison of wood harvesting systems in Northewest Russia. Applied Ergonomics. 2014;45(2):318-38. doi: 10.1016/j. apergo.2013.04.018

International Organization for StandardizationISO. ISO 2631-1: mechanical vibration and shock: evaluation exposure to whole-body vibration: Part. 1: general requirements. $2^{\mathrm{a}}$. ed. Geneva: International Organization for Standardization; 1997.

Ismoilov A, Sellgren U, Andersson K, Löfgrem B. A comparison of novel chassis suspended machinesfor sustainable forestry. Journal of Terramechanics. 2015;58(2):59-68.doi: 10.1016/j.jterra.2015.01.002

Marzano FLC, Souza AP, Minette LJ. Proposal for na ergonomic conformity index for evaluation of harvester and forwarders. Revista Árvore. 2017;41(4):1-8. doi: 10.1590/180690882017000400001

Osborne A, Blake C, Fullen BM, Meredith D, Phelan J, McNamara J, et al. Risk factorns for musculoskeletal disorders among farm owners and farm workers: A systematic review. American Journal of Industrial Medicine. 2012;55(4):376-89. doi: 10.1002/ajim.22001

Østensvik T, Veiersted KB, Cuchet E, Nilsen $\mathrm{P}$, Hanse JJ, Carlzon C, et al. A search for risk factors of upper extremity disorders among forest machine operators: A comparison between France and Norway. International Journal of Industrial Ergonomics. 2008;38(11-12): 1017-27. doi: 10.1016/j.ergon.2008.01.016

Prinz R, Spinelli R, Magagnotti N, Routa J, Asikainen A. Modifying the settings of CTL timber harvesting machines to reduce fuel consumption and $\mathrm{CO} 2$ emissions. Journal of Cleaner Production. 2018;197(1):208-17. doi: 10.1016/j. jclepro.2018.06.210

Rehn B, Lundström R, Nilsson L, Liljelind I, Järvholm B. Variation in exposure to wholebody vibration for operators of forwarder

Revista Árvore 2020;44:e4425 
vehicles - aspects on measurement strategies and prevention. International Journal of Industrial Ergonomics. 2005;35(9):831-42. doi: 10.1016/j. ergon.2005.03.001

Robert RCG, Brown RO, Ruy CC. Análisis económico de la cosecha mecanizada en repoblaciones de Eucalyptus spp. en sitios montañosos. Madera y bosques. 2018;24(3):1-12. doi: $10.21829 / \mathrm{myb} .2018 .2431621$

Santos DWFN, Fernandes HC, Valente DSM, Leite ES. Desempenho técnico, econômico e ambiental do harvester em distintas rotações do motor. Scientia Forestalis. 2018;46(118): 319-26. doi: 10.18671/ scifor.v46n118.17

Santos LN, Fernandes HC, Silva ML, Teixeira MM, Souza AP. Avaliação de custos da operação de extração da madeira com forwarder. Cerne. 2016;22(1):27-34. doi: $10.1590 / 01047760201622012076$

Silva EP, Minette LJ, Souza AP, Marçal MA, Sanches ALP. Fatores organizacionais e psicossociais associados ao riso de LER/DORT em operadores de máquinas de colheita florestal. Revista Árvore. 2013;37(5):889-95. doi: 10.1590/S010067622013000500011 